\title{
Evaluation of Formulated Concentrate Feeds on Feed Intake and Milk Yield of Lactating Upgraded Dairy Cows at Nekemte and ljaji Towns
}

\author{
Tesfaye Mediksa ${ }^{*}$, Dereje Bekele, Tesfaye Marsha, Habtamu Abera \\ Bako Agricultural Research Center, West Shoa, Bako, Ethiopia \\ Email address: \\ tesfishmidoo2008@gmail.com (T. Mediksa) \\ ${ }^{*}$ Corresponding author

\section{To cite this article:} \\ Tesfaye Mediksa, Dereje Bekele, Tesfaye Marsha, Habtamu Abera. Evaluation of Formulated Concentrate Feeds on Feed Intake and Milk \\ Yield of Lactating Upgraded Dairy Cows at Nekemte and Ijaji Towns. American Journal of Applied Scientific Research. \\ Vol. 7, No. 2, 2021, pp. 22-28. doi: 10.11648/j.ajasr.20210702.12
}

Received: January 13, 2021; Accepted: April 16, 2021; Published: June 22, 2021

\begin{abstract}
A study was carried out at urban and peri-urban areas of Nekemte and Ijaji towns to evaluate the effects of formulated concentrate feeds on feed intake and milk yield of upgraded dairy cows kept by smallholder dairy keepers. Twenty four lactating dairy cows within their $2^{\text {nd }}$ months after calving and with similar status were selected from smallholder dairy keepers under zero grazing system whereby feed intake, BCS and milk yield data were recorded for a period of 90 days. The cows were randomly allocated to four feeding groups (T1, T2, T3 and T4) in a completely randomized design (CRD). Cows in T1, T2, T3 and T4 were fed commercial dairy feed, recommended concentrate feed of ATRC, recommended concentrate feed of HARC and recommended concentrate feed of BARC, respectively. Basal diet for all dietary treatments were natural grass hay adlibtum. The average CP (\%) and IVDMD \% of the natural grass hay and recommended concentrates of BARC were (8.2, $7.95)$ and $(25.88,10.59)$, respectively. The daily concentrate DM) and CP intakes were significantly different $(\mathrm{p}<0.001)$ among the dietary treatments with highest values being registered for T4 $(8.2$ and $2.12 \mathrm{~kg} / \mathrm{d}$, respectively) and for T1 7.55 and $1.77 \mathrm{~kg} / \mathrm{d}$ respectively while the lowest values being registered for t T2 $(6.28$ and $1.3 \mathrm{~kg} / \mathrm{d}$, respectively) and for T3 $(5.83$ and $1.12 \mathrm{~kg} / \mathrm{d}$, respectively). The daily mean milk yields were higher $(\mathrm{P}<0.001)$ for cows in T4 (16.42 liter/day) and in T1 (15.10 liter/day) than those for those in T2 (12.55 liter/day) and in T3 (11.66 liter/day). Milk yield was also affected by location $(\mathrm{P}<0.001)$ with the highest milk yield being obtained at Nekemte town (15.15 liter/day) and the lowest at Ijaji town $(11.49$ liter/day). The largest change noted in variable costs was birr 120.79 per day and the change observed in net income was birr 361.24 per day, resulting in a marginal rate of return of $76.69 \%$ for T4. Among the concentrates recommended different research centers and the commercial concentrate, concentrate recommended at BARC and the commercial ones increased milk production and profitability of the dairy enterprise. Therefore, Feeding these concentrate types for upgraded lactating cows under smallholder dairy keepers is profitable both biologically and economically.
\end{abstract}

Keywords: Concentrate, Dairy, Feed Intake, Milk Yield

\section{Introduction}

The livestock sector has been contributing a considerable portion to the economy of Ethiopia, and still promising to rally around the economic development of the country. Dairy farming is expanding with high yielding crossbred cows flourishing in urban and peri-urban areas of Ethiopia. Urban and peri-urban dairy production systems are becoming important suppliers of milk and milk products to urban centers
[5] and contributing immensely towards filling the large demand-supply gap for milk and milk products in urban centers, where consumption of dairy products is remarkably high and they are the main suppliers of raw milk to processors of different scales [7]. However, this dairying is constrained by feed scarcity, both in terms of quantity and quality [32]. Reports have shown that breed improvement will lead to an improvement in milk productivity of cattle ranging from 60 to $300 \%$ if accompanied by better feeding regimes [16]. 
Home-mixed concentrate mixtures are blended using locally available feed ingredients in various proportions with no awareness of their quality and impact of nutrient imbalances to productive and reproductive performances of crossbred dairy cows. Nutrient concentrations in feeds vary considerably, and not all nutrients in feeds are equally available to the animal [2]. The usual practice by dairy producers to judge quality is mainly based on visual perceptions of mixed rations without laboratory based compositional confirmation [15]. In urban and periurban dairy production systems, the success of dairy production in general and crossbreeding programs in particular needs to be monitored regularly by assessing the productive and reproductive performances under the existing management, feed formulation and feeding of dairy cows.

The classical approach of increasing dairy production is through genetic means by crossing with improved breeds. Unless feeding management is improved, these animals may be limited to fully express their potential genetic superiority. It is fundamental approach to provide good quality diets to dairy cattle in sufficient amounts to maximize production. But in Ethiopia there is critical shortage of feed both in quantity and quality. The traditional feeding system for dairy cattle is based on the use of crop residues, and natural grazing supplemented with a little or no concentrates. According to [13], dairy farmers rarely feed concentrates at recommended levels and required quality. Thus, effective utilization of the available feed resources (agricultural and agro-industrial byproducts, natural pastures and browse) and appropriate supplementation of poor quality natural pasture and crop residue based diets appear to be the necessary step to alleviate the nutritional problems of dairy animals. Different supplementation strategies could be applied depending upon the type, accessibility and price of supplementary feeds in a given area.

Since feeding of these low protein roughages hardly support the maintenance requirements and leads to low production and reproduction of the ruminant livestock, various options to alleviate these constraints have been carried out both locally and globally among which upgrading them through supplementation with escape protein is the remarkable one. A supplement of bypass protein is the most important. Most of the oil seed plants such as noug (Guizotia abyssinica), linseed, groundnuts, rapeseed, sesame, cottonseed and sunflower are widely grown in Ethiopia. The cakes of these crops, after the oil is extracted are used as a protein supplement to low quality crop residues and hays. Thus, this study was initiated with the aim of evaluating the effects of formulated concentrate feeds on feed intakes and milk yield of upgraded dairy cows kept by smallholders in urban and peri-urban areas under zero grazing system.

\section{Materials and Methods}

\subsection{The Study Area}

An on-farm experiment was conducted on lactating upgraded dairy cows kept by dairy keepers in urban and peri- urban areas under zero grazing system during the dry season (January 2018 to march 2018) at Nekemte (East Wellega zone) and Ijaji (West Shoa zone).

\subsection{Preparation of Hay and Concentrate Feed}

Natural grass hay purchased from the local farmers around the town was used for the experiment. A concentrate mix sufficient for the entire experimental period was formulated on-station using milled Maize grain, wheat bran and Noug seed cake. This ration was formulated at BARC to fully meet the requirement for major nutrients of lactating crossbred cows with milk yield, butter fat and milk protein content as described in [19]. Representative samples were taken for laboratory analysis and DM and nutrient content of the diets were analyzed.

\subsection{Experimental Animals}

Twenty four farmers, having lactating upgraded cows in mid lactation ( 2 months after calving) were selected for the on-farm feeding trial based on their willingness to participate, commitment and presence of physical structure for monitoring feed intake. Milk yield of the cows ranged from 9.0 to $14.42 \mathrm{~kg} / \mathrm{cow} /$ day with an average of $11.4 \pm 0.41$ $\mathrm{kg} / \mathrm{cow} /$ day. Based on the level of milk yield, body condition and parity, the animals were divided into four equal groups (6 cows in each group):

\subsection{Experimental Diets, Feeding Management and Measurements}

The four groups were fed with, dietary treatment (1) composed of Natural grass hay adlibtum + Commercial dairy Ration, dietary treatment (2) composed of Natural grass hay adlibtum $+50 \%$ wheat bran $+48 \%$ noug cake $+2 \%$ salt), dietary treatment (3) composed of Natural grass hay adlibtum $+74 \%$ wheat bran $+25 \%$ noug cake $+1 \%$ salt and dietary treatment (4) composed of Natural grass hay adlibtum $+49.5 \%$ maize grain $+49.5 \%$ noug cake $+1 \%$ salt. The supplement diets were fed at the levels required to fulfill nutrient requirements of the cows based on [19]. The amounts of supplement fed to each cow in all dietary treatment during the entire experiment were at the rate of $0.5 \mathrm{~kg}$ per $\mathrm{kg}$ of milk production perday as per the previous recommendations. Adjustment of the concentrate supplement was made weekly based on the milk yield of each cow. The daily supplement allowance of each cow was divided into two equal parts and offered twice per day, in the morning and the evening milking times. The natural grass hay was offered ad libitum 3 times a day by weighing the daily allowance to ensure some amount of refusals (10-15\% of hay offered) next morning. Adjustment of roughage offered was made weekly based on the amount of refusal recorded every morning. All the cows were hand milked twice a day, in the morning and in the evening. Milk yield was measured daily and recorded right at milking. The selected animals were dewormed before the 
commencement of the experiment. The animals had free access to water throughout the experimental period.

\subsection{Duration, Monitoring and Data Recording}

The data were recorded over a period of 90 days after an adaptation period of 15 days. Field visits were carried out every two weeks to monitor the feed intake and milk yield of the animals. The body condition of each cow was scored at the beginning and end of the experiment on a scale of 1 through 5. Condition score 1 indicates severe under-condition and 5 indicates severe over-condition as described by [31]. Cows were scored on appearance and palpation of back and hind quarters only. The enumerators daily recorded the intake of roughage and concentrate and milk yield on pre-designed data recording sheet. These sheets were checked at each visit for accuracy and consistency. Feed samples were collected at monthly intervals and brought to the laboratory for further analysis. Perceptions of the participating farmers at the end of the experiment regarding the feasibility of different feed supplementation were assessed.

\subsection{Sampling and Analytical Techniques}

Samples of the feeds obtained during the experiment were bulked, ground and analyzed for dry matter (DM), organic matter (OM) and crude protein (CP) according to the standard procedures of AOAC (1995). Neutral detergent fiber (NDF), acid detergent fiber (ADF) and lignin were determined by the method of [27]. The two stage in vitro technique developed by [24] was used to determine In vitro Organic Matter Digestibility (IVOMD) of the feeds.

\subsection{Partial Budget Analysis}

Economic analysis was based on calculations of the total cost of production and the income from milk sales. The prices of feeds and milk were obtained from the prevailing market price in the area during the experimental period. The net profit/cow/day was calculated for the whole experimental period as a difference between the cost of production and the income generated from milk sales.

\subsection{Statistical Analysis}

Voluntary DM and nutrient intakes, BCS and milk yield were subjected to GLM procedure for CRD using Statistical Analysis System (SAS, 2002).

Treatment means were separated using Least Significant difference (LSD). The model used for the analysis of data was:

$$
\mathrm{Yij}=\mu+\mathrm{Li}+\mathrm{Tj}+\mathrm{Eij}
$$

Where; $\mu=$ Overall mean

$\mathrm{Li}=$ Location effect (place)

$\mathrm{Tj}=$ Treatment effect

Eijk=Experimental error

\section{Results and Discussions}

\subsection{Chemical Composition of Feeds}

The chemical compositions of feeds are shown in Table 1. The CP content of hay offered to the experimental animals in the current study was higher than the $7.02 \% \mathrm{CP}$ reported by [1] and almost similar with the findings of [25] who reported $8.4 \%$ CP content. Feeds that contain lower proportion of ADF have better availability of nutrients due to ADF being negatively correlated with feed digestibility [17]. The ADF value observed in the hay used in the current study was higher than the $37.59 \%$ reported by [25].

The supplemental concentrates had higher CP and lower NDF concentrations relative to the basal diet. The NDF values of the supplemental feeds are lower than the 55\% reported by [28] to limit appetite and digestibility. According to [22], roughages with NDF content of $45-65 \%$ are generally categorized as medium quality feeds, while feeds with NDF below $45 \%$ are grouped as high quality feeds. The concentrate mix used in the present study with NDF values ranging from $39.22-42.53 \%$ fall in the category of high quality feeds, The IVOMD of NGH used in the present study was less than the 59.3\% IVOMD reported for native hay at BARC, and the $61.5 \%$ reported for hay harvested from Bako area [11]. The difference in chemical composition might have occurred as a result of the stage of harvest.

Table 1. Chemical composition of feed used for the experiment.

\begin{tabular}{|c|c|c|c|c|c|c|c|}
\hline Parameter & DM (\%) & Ash (\%) & CP (\%) & NDF (\%) & ADF (\%) & ADL (\%) & IVDMD (\%) \\
\hline ATARC (Concentrate feed recommendation) & 91.88 & 11.41 & 23.5 & 41.47 & 16.16 & 4.35 & 66.44 \\
\hline Commercial dairy ration & 91.35 & 8.74 & 20.81 & 41.98 & 18.05 & 4.42 & 68.01 \\
\hline HARC (Concentrate feed recommendation) & 90.96 & 8.64 & 19.19 & 42.53 & 14.49 & 2.66 & 69.5 \\
\hline BARC (Concentrate feed recommendation) & 92.49 & 11.62 & 25.88 & 39.22 & 18.78 & 6.56 & 66.21 \\
\hline Natural grass Hay & 92.61 & 11.26 & 8.2 & 72.6 & 48.9 & 10.87 & 49.7 \\
\hline
\end{tabular}

ATARC: Adami Tulu Agricultural Research Center, HARC: Holetta Agricultural Research Center and BARC: Bako Agricultural Research Center

\subsection{Dry Matter and Nutrients Intakes}

The daily DM and nutrient intake of lactating Upgraded Dairy Cows fed hay supplemented with different concentrate mix are presented in Table 2. The difference in daily DM intake was highly significant $(P<0.001)$ among treatments.
The highest daily dry matter intake was observed when cows were fed dietary treatment $\mathrm{T} 4$ and $\mathrm{T} 1$. The difference could be attributed to high energy and protein concentration in these treatments, which might have enhanced the efficiency of rumen microorganisms that increased fiber degradability and digestibility thereby improving feed intake ([17]. 
Animals consume more of the feeds containing better protein as compared to those containing less protein [23].

Intake of feed by ruminant can be improved through concentrate supplementation [2]. Addition of CP supplement may stimulate efficient rumen fermentation, more passage rate and intake [30]. This implies the presence of direct relationship between $\mathrm{CP}$ content of feeds and feed intake. Earlier report [6] showed improvement in the daily total DM intake due to supplementation. This may be attributed to the ability of the supplements to provide nitrogen and energy for the cellulolytic microbes upon degradation in the rumen [29] and increases the nitrogen content of the total diet, which in turn is likely to increase feed intake and the rate of degradation of the basal diet in the rumen [9]. When the rate of breakdown of digesta increases, feed intake increases accordingly [26]. [18] reported that if the ingested feed is retained longer in the rumen, it is expected that the animal would consume less feed, because of the occupied space or 'gut fill'. The highest $(\mathrm{p}<0.001) \mathrm{DM}$ intake obtained for T4 and T1 might have arisen from the more balanced intakes of both $\mathrm{CP}$ and ME that have led to a more efficient utilization of the fiber in the total diet, which is in agreement with other studies [14].

The CP intake has shown significant difference $(\mathrm{P}<0.001)$ among the dietary treatments with high values for dietary treatment $\mathrm{T} 4$ due to the relatively higher $\mathrm{CP}$ content of the feed. As far as protein requirements are concerned, the $\mathrm{CP}$ intake in all treatments of the present study was higher than the estimated daily $\mathrm{CP}$ requirement $(866.5 \mathrm{~g} / \mathrm{d})$ of lactating cows producing $8-10 \mathrm{~kg}$ milk with $4.5 \%$ butter fat per day [3].

The intake of $A D F$ and $A D L$ were higher in T4 $(p<0.001)$ as compared to the intake in other treatments. This is likely to be due to the corresponding higher total DM consumed by the cows in that treatment. IVDMD intake among the treatments was highly significant $(P<0.001)$. Higher IVDMD intake was observed in T1 and T4 compared to other treatments.

Table 2. DM and nutrient intakes and IVDMD of the Dairy Cows supplemented with different concentrate mix in $\mathrm{kg} /$ day.

\begin{tabular}{|c|c|c|c|c|c|c|c|}
\hline \multirow{2}{*}{ Treatments } & \multicolumn{7}{|l|}{ Parameter } \\
\hline & DM & ASH & $\mathrm{CP}$ & NDF & ADF & ADL & IVDMD \\
\hline 1 & $6.94^{\mathrm{a}} \pm 0.49$ & $0.86^{\mathrm{b}} \pm 0.06$ & $1.77^{\mathrm{b}} \pm 0.12$ & $3.13^{\mathrm{a}} \pm 0.22$ & $1.22^{\mathrm{b}} \pm 0.09$ & $0.33^{\mathrm{b}} \pm 0.22$ & $5.01^{\mathrm{a}} \pm 0.36$ \\
\hline 2 & $5.73^{b} \pm 0.74$ & $0.55^{\mathrm{c}} \pm 0.07$ & $1.30^{c} \pm 0.17$ & $2.63^{b} \pm 0.33$ & $1.13^{\mathrm{b}} \pm 0.14$ & $0.28^{\mathrm{c}} \pm 0.04$ & $4.27^{\mathrm{b}} \pm 0.55$ \\
\hline 3 & $5.30^{\mathrm{b}} \pm 0.38$ & $0.50^{\mathrm{c}} \pm 0.04$ & $1.12^{\mathrm{c}} \pm 0.08$ & $2.48^{\mathrm{b}} \pm 0.17$ & $0.85^{\mathrm{c}} \pm 0.06$ & $0.16^{\mathrm{d}} \pm 0.01$ & $4.05^{b} \pm 0.29$ \\
\hline 4 & $7.60^{\mathrm{a}} \pm 0.77$ & $0.95^{\mathrm{a}} \pm 0.09$ & $2.12^{\mathrm{a}} \pm 0.21$ & $3.22^{\mathrm{a}} \pm 0.33$ & $1.54^{\mathrm{a}} \pm 0.16$ & $0.54^{\mathrm{a}} \pm 0.06$ & $5.44^{\mathrm{a}} \pm 0.54$ \\
\hline SE & 0.25 & 0.028 & 0.062 & 0.11 & 0.05 & 0.015 & 0.18 \\
\hline SL & $* * *$ & $* * *$ & $* * *$ & $* * *$ & $* * *$ & $* * *$ & $* * *$ \\
\hline
\end{tabular}

T1: Hay + Commercial dairy ration, T2: Hay $+48 \%$ Noug cake $+50 \%$ Wheat bran $+2 \%$ salt (ATARC recommendation), T3: Hay $+25 \%$ Noug cake $+74 \%$ Wheat bran $+1 \%$ salt (HARC recommendation) and T4: Hay $+49.5 \%$ Noug cake $+49.5 \%$ Maize grain $+1 \%$ salt (BARC recommendation), SE: standard error, SL: significance level

\subsection{Milk Yield}

The results of daily milk yield of Upgraded Dairy Cows fed concentrate mix are shown in Table 3 . Daily milk yield was significantly different among treatments $(\mathrm{P}<0.0001)$ being higher for cows in $\mathrm{T} 4$ and $\mathrm{T} 1$ as compared to those in the other treatments. The difference in milk yield among treatment groups is attributed to the differences in crude protein and energy contents of the diets [23, 12]. Indicated that supplemented cows produced significantly more milk than the unsupplemented ones.

In this experiment both the $\mathrm{CP}$ and $\mathrm{ME}$ intakes were sufficient to meet requirement for the observed milk yield. The mean daily milk yield obtained from cows in the present study was almost comparable to the values of $16.6 \mathrm{~kg} \mathrm{~d}^{-1}$ reported by [10]. The variation between different reports might be due to the differences in IVDMD intake and intrinsic factors like level of production, parity, stage of lactation, external factors like environmental stress, and unequal intervals between milking and changes in feeding.

Table 3. Milk yield and body condition score of the Dairy Cows supplemented with different concentrate mix in $\mathrm{kg} / \mathrm{day}$.

\begin{tabular}{|c|c|c|c|c|c|c|}
\hline \multirow{2}{*}{ Parameter } & \multicolumn{4}{|l|}{ Treatments } & \multirow{2}{*}{ SE } & \multirow{2}{*}{ SL } \\
\hline & 1 & 2 & 3 & 4 & & \\
\hline MY (littre/day) & $15.10^{\mathrm{a}} \pm 1.07$ & $12.55^{\mathrm{b}} \pm 1.61$ & $11.66^{\mathrm{b}} \pm 0.83$ & $16.42^{\mathrm{a}} \pm 1.66$ & 0.55 & $* * *$ \\
\hline $\mathrm{BCS}$ & $3.33 \pm 0.52$ & $3.5 \pm 0.55$ & $3.33 \pm 0.82$ & $3.5 \pm 0.55$ & 0.25 & ns \\
\hline Concentrate $(\mathrm{kg} / \mathrm{d})$ & $7.55^{\mathrm{a}} \pm 0.54$ & $6.28^{\mathrm{b}} \pm 0.80$ & $5.83^{\mathrm{b}} \pm 0.42$ & $8.20^{\mathrm{a}} \pm 0.83$ & 0.27 & $* * *$ \\
\hline Hay intake $(\mathrm{kg} / \mathrm{d})$ & $11.20 \pm 0.4$ & $9.50 \pm 0.6$ & $9.30 \pm 0.55$ & $10.40 \pm 0.45$ & 1.10 & ns \\
\hline
\end{tabular}

T1: Hay + Commercial dairy ration, T2: Hay $+48 \%$ Noug cake $+50 \%$ Wheat bran $+2 \%$ salt (ATARC recommendation), T3: Hay $+25 \%$ Noug cake $+74 \%$ Wheat bran $+1 \%$ salt (HARC recommendation) and T4: Hay $+49.5 \%$ Noug cake $+49.5 \%$ Maize grain $+1 \%$ salt (BARC recommendation), My: milk yield, BCS: body condition score, FI: feed intake, SE: standard error, SL: significance level.

The results of daily milk yield and feed intake of Upgraded Dairy Cows fed concentrate mix are shown in Table 4. Daily milk yield were significantly different between location $(\mathrm{P}<0.0001)$ with high milk yield for cows in Nekemte town and lower for cows in Ijaji. This is likely to be due to the fact that Nekemte town is highland and convenient for dairy rearing as compared to Ijaji which is somewhat hot area. The daily feed intake was also high in 
Nekemte town as compared to in Ijaji town $(\mathrm{P}<0.0001)$ because the cows feed intake was $\mathrm{f}$ high in highland as compared to in midland.

Table 4. Effect of location on Feed intake, milk yield and body condition score of the Dairy Cows supplemented with different concentrate mix.

\begin{tabular}{lllll}
\hline \multirow{2}{*}{ Parameter } & \multicolumn{2}{l}{ Location } & \multirow{2}{*}{ SE } & \multirow{2}{*}{ SL } \\
\cline { 2 - 3 } & Nekemte & Ijaji & & \\
\hline MY (Littre/day) & $15.15^{\mathrm{a}} \pm 1.13$ & $11.49^{\mathrm{b}} \pm 1.70$ & 0.47 & $* * *$ \\
BSC & $3.5 \pm 0.52$ & $3.25^{ \pm} \pm 0.71$ & 0.18 & $\mathrm{~ns}$ \\
FI (kg/day) & $7.58^{\mathrm{a}} \pm 0.85$ & $5.75^{\mathrm{b}} \pm 0.56$ & 0.23 & $* * *$ \\
\hline
\end{tabular}

MY: milk yield, BCS: body condition score, FI: feed intake, SE: standard error, SL: significance level Table 3. Effect of concentrate feed intake on milk yield and body condition of Upgraded Dairy Cows at Nekemte and Ijaji town

\subsection{Partial Budget Analysis}

The economic feasibility of this study was analyzed using partial budget analysis. According to this analysis, T4 gave higher net benefit (Birr 240.45 per cow/day), than other treatments. The minimum rate of return acceptable by the dairy farmer was assumed to be $50 \%$ [8]. This implies that the dairy farmer expects a minimum rate of return of $50 \%$ if he is to adopt a new practice as compared to the practice he used to do. Change in cost that varies was birr 28.04 per day and the change in net income was birr 76.68 per day resulting in $273.47 \%$ marginal rate of return for T4. So, for each birr invested as input for a cow, the farmer will recover birr 1.00 and an additional birr 2.73 at a given prices. Therefore, on the basis of MRR the technology is recommended for increasing milk productivity of cows. The result of MRR of the present study was in the profitable range of $158 \%$ and $131.85 \%$ reported by [21] for milking cows and buffaloes, respectively. Therefore, considering milk yield and economic return in this study, it can be concluded that cows fed with concentrate diet of $\mathrm{T} 4$ with adlibtum hay optimize both biological and economic benefits as compared to cows consumed with other treatment feeds (Table 5).

Table 5. Partialbudget analysisfor lactatingUpgraded Dairy Cowsfed natural grass hay asbasaldiet andsupplementedwith concentrate mix (0.5kg/1milk).

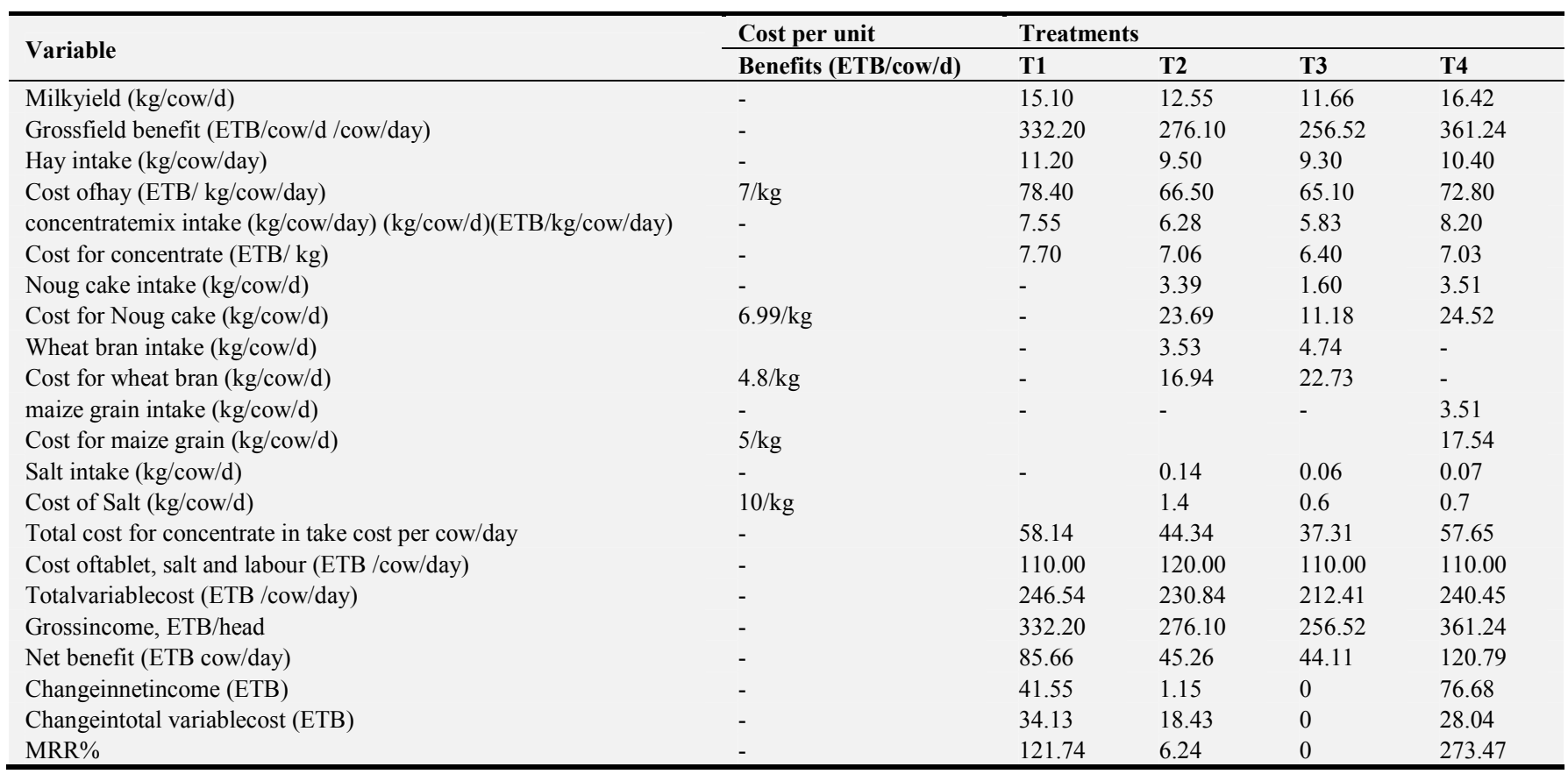

Ethiopian Birr; MRR=Marginal Rate of Return;

T1: Hay + Commercial dairy ration, T2: Hay $+48 \%$ Noug cake $+50 \%$ Wheat bran $+2 \%$ salt (ATARC recommendation), T3: Hay $+25 \%$ Noug cake $+74 \%$ Wheat bran $+1 \%$ salt (HARC recommendation) and T4: Hay $+49.5 \%$ Noug cake $+49.5 \%$ Maize grain $+1 \%$ salt (BARC recommendation)

\subsection{Dairy Keepers' Perception}

Participants noticed that the benefits of feeding the intervention diet were immediately visible. Dairy keepers noticed that cow's in $T_{1}$ and $T_{2}$ eat the concentrate feed more quickly as compared to cows in the other treatments. Furthermore, after feeding the intervention diet, an increase in milk production and an improvement in fertility levels (cows show more intensely the characteristic of being on heat) were noted.

\section{Conclusion and Recommendations}

The results of the present study lead to acceptance of the fact that using feed of high protein and energy sources can increase milk yield of upgraded dairy cows. Upgraded lactating cows under dairy keepers at Nekemte and Ijaji towns are profitable both biologically and economically. Among the different recommended concentrate at different research centers and a commercial ration, BARC concentrate recommendation and the commercial ration increased milk production and profitability of the dairy enterprise. These 
feeds are then recommended as supplemental feeds for crossbred dairy cows.

\section{Acknowledgements}

The financial support of Oromia Agricultural Research Institute is gratefully acknowledged.

\section{References}

[1] Abebaw Nega, 2007. Effects of supplementation with rice bran, noug seed (Guizotia abyssinica) cake and their mixtures on feed utilization and live weight change of farta sheep. An MSc Thesis Presented to the School of Graduate Studies of Haramaya University. 92p.

[2] Adugna T 2008. Feed resources and feeding management: A manual for feedlot operators and development workers. Ethiopia Sanitary and Phytosanitary Standards and Livestock $\&$ Meat Marketing Program (SPS-LMM) USAID, Ethiopia. $38 \mathrm{p}$.

[3] Agricultural Research Council, 1990. The nutrient requirement of ruminant livestock. Common Wealth Agricultural Bureaux. Slough, England. UK.

[4] AOAC (Association of Official Analytical Chemists), 1995. Official Methods of Analysis. pp. 5-13. (16th edition), Washington DC, USA.

[5] Azage T, Berhanu G, Hoekstra D, Berhanu B and Yoseph M 2013. Smallholder dairy production and marketing systems in Ethiopia: IPMS experiences and opportunities for marketoriented development. IPMS (Improving Productivity and Market Success) of Ethiopian Farmers Project Working Paper 31. Nairobi: Kenya. 65p.

[6] Ba, N. X., Doyle, P. T., Van Hai, D., Lane, P. A., MalauAduli, A. E., Van, N. H. and Parsons, D., 2015. Effect of concentrate supplementation on nutrient digestibility and growth of Brahman crossbred cattle fed a basal diet of grass and rice straw. Journal of animal science and technology, 57 (1), p. 35 .

[7] Belay D, Yisehak K and Janssens G P J 2012. Productive and reproductive performance of Zebu $\mathrm{X}$ Holstein-Friesian crossbred dairy cows in Jimma Town, Oromia, Ethiopia. Global Veterinaria, 8 (1): 67-72.

[8] CIMMYT, 1985. From Agronomic Data to Farmers Recommendations. Economics Programme. Mexico. 32p.

[9] De Almeida Rufino, L. M., Detmann, E., Gomes, D. Í., dos Reis, W. L. S., Batista, E. D., de Campos Valadares Filho, S. and Paulino, M. F., 2016. Intake, digestibility and nitrogen utilization in cattle fed tropical forage and supplemented with protein in the rumen, abomasum, or both. Journal of animal science and biotechnology, 7 (1), p. 11.

[10] Demski, J. B., Arcaro Junior, I., Gimenes, F. M. D. A., Toledo, L. M. D., Miranda, M. S. D., Giacomini, A. A. and Silva, G. A. D., 2019. Milk production and ingestive behavior of cows grazing on Marandu and Mulato II pastures under rotational stocking. Revista Brasileira de Zootecnia, 48.

[11] Diriba Geleti, Mekonnen Hailemariam, Ashenafi Mengistu \& Adugna Tolera, 2013. Nutritive Value of Selected Browse and
Herbaceous Forage Legumes Adapted to Medium Altitude Subhumid Areas of Western Oromia, Ethiopia. Global Veterinaria, 11 (6): 809-816.

[12] Falk, M., Münger, A., Zbinden, R. S., Gross, J. J., Bruckmaier, R. M., Hess, H. D. and Dohme-Meier, F., 2018. Effects of concentrate supplementation in early lactation on nutrient efficiency, ruminal fermentation and reticular $\mathrm{pH}$ of zerograzing dairy cows with differing milk production potentials. Journal of animal physiology and animal nutrition, 102 (6), pp. 1497-1508.

[13] Gillah K A, Kifaro G C and Madsen J 2012: Urban and peri urban dairy farming in East Africa: A review on production levels, constraints and opportunities. Livestock Research for Rural Development. Volume 24, Article \#198. Retrieved May 13, 2020, from http://www.lrrd.org/lrrd24/11/gill24198.htm.

[14] Huhtanen, P., Nousiainen, J. I., Rinne, M., Kytölä, K. and Khalili, H., 2008. Utilization and partition of dietary nitrogen in dairy cows fed grass silage-based diets. Journal of dairy science, 91 (9), pp. 3589-3599.

[15] Land O'Lakes, Inc2010 The next stage in dairy development for Ethiopia. USAID. Addis Ababa, Ethiopia. Pp. 20-32.

[16] McDermott J J, Staal S J, Freeman H A, Herrero M and Van de Steeg J A2010 Sustaining intensification of smallholder livestock systems in the tropics. Livestock Science, 130: 95109.

[17] McDonald, P., Edwards. R. A, Greenhalgh. J. D and Morgan C. A, 2002. Animal Nutrition $6^{\text {th }}$ edition. Longman. United Kingdom. 607p.

[18] Moyo, M. and Nsahlai, I. V., 2018. Rate of Passage of Digesta in Ruminants; Are Goats Different?. Goat science, IntechOpen, pp. 39-74.

[19] NRC, 2001. Nutrient requirements of dairy cattle. 7th rev. ed. Natl. Acad. Sci., Washington, DC. USA.

[20] SAS (Statistical Analysis S ystem), 2002. SAS InstituteInc, $\mathrm{NC}$, USA.

[21] Shah H, Sharif M, Majid A, Hayat U and Munawar A, 2009: From experimental data to farmer recommendation: an economic analysis of on-farm trial of UMMB feed for milking animals in rain-fed Pothwar, Pakistan. Livestock Research for Rural Development. 21 (117). Retrieved August 11, 2014, from http://www.lrrd.org/lrrd21/8/shah21117.htm.

[22] Singhal, K K. D. D. Sharma and P. S. Oberoi, 1992. Comparative nutrient utilization of ammoniated paddy straw in cattel and buffaloes. Indian Journal of Animal Nutrition, 9: $39-44$.

[23] Steinshamn. H, 2010. Effect of forage legumes on feed intake, milk production and milk quality a review. Animal Science Papers and Reports. 28 (3): 195-206.

[24] Tilley, J. M. A. and R. A. Terry, 1963. Atwo-stagetechniquefo rin Vitro digestion of foragecrops. Journal of the British Grassl and Society, 18: 104.

[25] Tulu, A., Khushi, Y. R. and Challi, D. G., 2018. Supplementary value of two Lablab purpureus cultivars and concentrate mixture to natural grass hay basal diet based on feed intake, digestibility, growth performance and net return of Horro sheep. Int J Livestock Prod, 9 (6), pp. 140-50. 
[26] Van Soest, P. J. Nutritional ecology of the Ruminant. Cornell University. O and B Books, Inc. USA, 1982.

[27] Van Soest, P. J, 1994. Nutritional Ecology of the Ruminant, Comstock Publishing Associates. A division of Cornell University Press, Ithaca and London.

[28] Van Soest, P. J., 1965. Symposium of factors influencing the voluntary intake in relation to chemical composition and digestibility. Journal Animal Science, 24: 834p.

[29] Wambui, C. C., S. A. Abdulrazak and Q. Noordin, 2006. The effect of supplementing urea treated maize stover with tithonia, calliandra and sesbania to growing goats. Livestock Research for Rural Development, 18 (5): 64.
[30] Wanapat, M., Kang, S. and Polyorach, S., 2013. Development of feeding systems and strategies of supplementation to enhance rumen fermentation and ruminant production in the tropics. Journal of Animal Science and Biotechnology, 4 (1), p. 32.

[31] Wildman et al., 1982. A dairy cow body condition scoring system and its relationship to selected production characteristics ME. E. Wildman, G. M. Jones, P. E. Wagner, R. L. Boman, H. F. Troutt Jr., T. N. Lesch.

[32] Zelalem Y, Emmanuelle G B and Ameha S 2011 A review of the Ethiopian dairy sector. Rudolf Fombad (eds), Food and Agriculture Organization of the United Nations, Sub-Regional Office for Eastern Africa (FAO/SFE), Addis Ababa, Ethiopia. $81 \mathrm{p}$. 